\title{
Respiratory manifestations in patients with inherited metabolic diseases
}

\author{
Francesca Santamaria, Silvia Montella, Virginia Mirra, Sara De Stefano, \\ Generoso Andria and Giancarlo Parenti
}

\author{
Affiliations: Dept of Paediatrics, Federico II University, Naples, Italy. \\ Correspondence: F. Santamaria, Dept of Paediatrics, Federico II University, via Pansini 5, 80131 Naples, Italy. \\ Email: santamardunina.it
}

\begin{abstract}
Growing evidence indicates that inherited metabolic diseases are increasingly being recognised. Life expectancy for many patients is progressively improving because new therapeutic strategies are available. Because most inherited metabolic diseases are systemic disorders, virtually all organs may be involved. Respiratory disease complicates the management of several inherited metabolic diseases, either at presentation or as late-onset features. This review will describe the most exemplary respiratory manifestations of inherited metabolic diseases in childhood and adulthood. Since airways disease worsens the morbidity of many inherited metabolic disorders, leading to increased hospitalisations, mortality and overall healthcare costs, respiratory manifestations of inherited metabolic diseases need to be carefully recognised and treated. All patients with inherited metabolic disease and suspected airway disease should undergo a detailed diagnostic work-up. Current treatments for several inherited metabolic diseases (including enzyme replacement therapy, substrate reduction, bone marrow transplantation, or even more innovative strategies such as pharmacological chaperone or gene therapies) may provide significant benefits for associated respiratory disease. The integration of several specialists dedicated to airway disease management in a multidisciplinary team is essential to provide the most appropriate care to children and adults with inherited metabolic disease.
\end{abstract}

0 @ERSpublications

Proper management of respiratory disease is mandatory for reducing morbidity and mortality of inherited metabolic disease http://ow.ly/oiHwo

\section{Introduction}

Approximately 400 human diseases due to inborn errors of metabolism are recognised. This number is increasing as novel techniques become available and allow for the identification of new biochemical and molecular abnormalities [1]. The vast majority of inherited metabolic diseases are caused by enzymes and transport protein abnormalities.

Because most inherited metabolic diseases are systemic, virtually all organs may be involved. During the past decades, research has expanded and multidisciplinary efforts by several specialists have succeeded in defining the complex phenotype [2]. Many disorders cause respiratory disease, which is often not immediately associated with inherited metabolic disease. Regrettably, the literature mainly describes anecdotal cases or small series reports.

Respiratory manifestations are part of the clinical picture of several inherited metabolic diseases, either at presentation or as late-onset features. Laryngeal stridor was reported as a leading presentation of biotinidase deficiency [3]. Polypnoea is a frequent neonatal feature of congenital lactic acidoses [2]. Interstitial lung

Received: Dec 192012 | Accepted after revision: Jan 062013

Conflict of interest: None declared.

Provenance: Submitted article, peer reviewed.

Copyright OERS 2013. ERR articles are open access and distributed under the terms of the Creative Commons Attribution Non-Commercial Licence 3.0. 
disease (ILD) and pulmonary hypertension are by far the most frequently described complications in lysosomal storage disorders. Pulmonary hypertension may be seen in non-ketotic hyperglycaemia [4], and was described in glycogenoses type I [5, 6], inborn errors of intracellular cobalamin metabolism [7], HUPRA (hyperuricaemia, pulmonary hypertension, renal failure and alkalosis) syndrome and in Wolman disease $[8,9]$. Several inherited metabolic diseases involve nervous or neuromuscular systems, are usually progressive, and often cause chronic airway aspiration and respiratory infections. This is the case of some organic acidaemia [10,11] and of several mitochondrial disorders [12]. Immune defects, such as chronic neutropenia or lymphocyte impairment, are described in some inherited metabolic diseases (glycogenosis Ib and hereditary orotic aciduria), and may explain the development of marked susceptibility to airway infections $[13,14]$. Inherited metabolic disorders with neurological involvement leading to severe disability can be associated with progressive chest and spine deformities, which predispose to respiratory insufficiency as a consequence of mechanical impairment. Finally, pulmonary complications taken together can cause significant disability and are the usual cause of premature death.

Inherited metabolic diseases may affect the upper and lower airways, the thoracic wall and all muscles involved in ventilation. In lysosomal storage disorders lower airway involvement may derive from accumulation of abnormal metabolites and/or macrophages with intracytoplasmatic metabolites in the airspaces and interstitium, or from chronic airway aspiration due to swallowing disorders associated with neuromotor delay. Alveolar hypoventilation due to respiratory muscle dysfunction and/or abnormal respiratory mechanics related to enlarged abdominal organs may develop in glycogenoses and lysosomal disorders. Obstructive sleep apnoea syndrome (OSAS) due to craniofacial abnormalities and/or upper and middle airway soft tissue anomalies is frequently reported in mucopolysaccharidoses (MPS). Finally, pulmonary hypertension that complicates some lysosomal disorders may be due to the chronic hypoxaemia secondary to ILD, associated liver disease with intrapulmonary shunting, or to infiltration of pulmonary vessels by abnormal cells or metabolites (table 1) [15-17].

Herein we will describe the most exemplary respiratory manifestations of inherited metabolic diseases by using paradigmatic models of selected disorders. We will also consider the assessments that should be included in patient management and will discuss whether and how available treatments are effective in inherited metabolic disease-associated airway disease.

\section{Lysosomal disorders}

Niemann-Pick disease

Niemann-Pick disease types A and B result from the deficient activity of sphingomyelinase, a lysosomal enzyme encoded by the SMPD1 gene [18]. The defect results in the pathological accumulation of sphingomyelin and others lipids in the monocyte-macrophage system. The progressive deposition of sphingomyelin in various organs is responsible for the neurodegenerative course of Niemann-Pick type A and for the systemic manifestations of Niemann-Pick type B, which include progressive lung disease in some patients [19]. Niemann-Pick disease type C is a different disorder due to either NPC1 or NPC2 gene mutations that severely impair intracellular lipid transport and cause accumulation of unesterified cholesterol and several glycosphingolipids in some tissues and organs, especially the brain [20-22]. Dysphagia increases the risk of silent and nonsilent aspirations and lung infections [23].

Although lung involvement in Niemann-Pick disease is frequently reported, its prevalence is unknown. In a French study of 13 children with Niemann-Pick disease types A, B and C, who were nevertheless selected based on their respiratory symptoms, chronic pulmonary disease or fatal respiratory failure were evident during the follow-up in all cases [24]. The clinical spectrum of manifestations includes wheezing, lower

TABLE 1 Major respiratory manifestations in inherited metabolic diseases

\begin{tabular}{|c|c|c|c|c|c|}
\hline ILD & $\begin{array}{l}\text { Lower airways } \\
\text { infections }\end{array}$ & $\begin{array}{l}\text { Chronic airway } \\
\text { aspiration }\end{array}$ & $\begin{array}{c}\text { Pulmonary } \\
\text { hypertension }\end{array}$ & $\begin{array}{c}\text { Alveolar } \\
\text { hypoventilation }\end{array}$ & $\begin{array}{c}\text { Upper airway } \\
\text { obstruction } \pm \text { OSAS }\end{array}$ \\
\hline $\begin{array}{l}\text { Lysosomal disorders } \\
\text { Lysinuric protein } \\
\text { intolerance }\end{array}$ & $\begin{array}{l}\text { Lysosomal disorders } \\
\text { Lysinuric protein } \\
\text { intolerance } \\
\text { Glycogenosis type I and II } \\
\text { Farber disease } \\
\text { Hereditary orotic aciduria }\end{array}$ & $\begin{array}{l}\text { Niemann-Pick type A and C } \\
\text { Gaucher disease type II and } \\
\text { III (neuronopathic form) } \\
\text { Organic acidaemias } \\
\text { Mitochondrial disorders }\end{array}$ & $\begin{array}{c}\text { Gaucher disease type I } \\
\text { Glycogenosis type la } \\
\text { and Ib } \\
\text { Wolman disease }\end{array}$ & $\begin{array}{c}\text { Glycogenosis type II } \\
\text { Mitochondrial disorders } \\
\text { Mucopolysaccharidoses } \\
\text { Inherited metabolic diseases with enlarged } \\
\text { abdominal organs (e.g. lysosomal disorders) } \\
\text { and/or neurological involvement }\end{array}$ & Mucopolysaccharidoses \\
\hline
\end{tabular}

ILD: interstitial lung disease; OSAS: obstructive sleep apnoea syndrome. 
airways infections and reduced exercise tolerance [25]. In a study from Turkey the evaluation of bronchoalveolar lavage (BAL) or lung biopsy in type B disease showed abnormal macrophages (foamy cells or Niemann-Pick cells) which typically accumulate within the alveolar spaces, the lymphatic interlobular vessels and the sub-pleural spaces [26].

In Niemann-Pick disease type A, which is dominated by early, severe neurological deterioration, ILD evidence on chest radiography was reported less frequently than in type B [27]. Most infants with type A disease may experience minimal respiratory difficulty in the first year of life, but recurrent bronchitis or aspiration pneumonia culminating in life-threatening or fatal events were reported [20]. Patients with Niemann-Pick disease type B may be asymptomatic for years or have only mild dyspnoea on exertion, but in some cases a fatal pulmonary disease was described [24, 26, 28]. Diffuse interstitial and nodular infiltrates with basal predominance, as well as honeycombing on chest radiography, or ground-glass opacities on chest high-resolution computed tomography (HRCT), may be regularly found in young children and in adults with type $\mathrm{B}$ disease $[24,25,29]$ even in the absence of functional abnormalities [30]. Patients with Niemann-Pick disease type C may have diffuse ILD as a presenting feature, or aspiration pneumonia because of neurological disease [23,31,32]. Finally, it has been reported that a small subset of infants with the severe NPC2 mutation may develop respiratory insufficiency due to pulmonary alveolar proteinosis (PAP) [33]. Figure 1 shows the typical chest radiograph findings in Niemann-Pick disease type A and the HRCT features in Niemann-Pick disease type C.

As many patients with Niemann-Pick disease experience respiratory manifestations, sometimes primarily, they should be referred early to a paediatric or adult pulmonologist to establish a detailed schedule of followup visits and investigations. Routine HRCT should be recommended in cases with symptoms and signs suggestive of pulmonary disease that might benefit from whole lung lavage as treatment $[34,35]$.

\section{Gaucher disease}

Gaucher disease is caused by a deficiency of glucocerebrosidase ( $\beta$-glucosidase) activity [36]. The hallmark of Gaucher disease is the presence of lipid-laden macrophages (Gaucher cells) in a variety of tissues, the largest number of them being found in the spleen, liver, bone marrow, lymph nodes and the central nervous system.

A significant phenotypic variability resulting from Gaucher disease genetic heterogeneity has been reported $[37,38]$. The substitution of serine for asparagine at amino acid residue 370 (the N370S mutation) is associated with type I disease (non-neuronopathic variant), whereas a substitution of proline for leucine at amino acid residue 444 (the L444P mutation) is associated with type II and type III homozygous state diseases (acute and subacute neuronopathic variants, respectively) [37]. Homozygosity for the L444P mutation is associated in almost all cases with type III Gaucher disease [36]. In patients homozygous for the D409H mutation, the phenotypic manifestations including oculomotor apraxia, splenomegaly, and cardiac valve and big vessel calcifications correlated with this genotype [39].

Lung involvement was described in all Gaucher disease types, and in more than one-third of the subjects examined post mortem [40]. Most of the cases with recurrent pulmonary infections and progressive
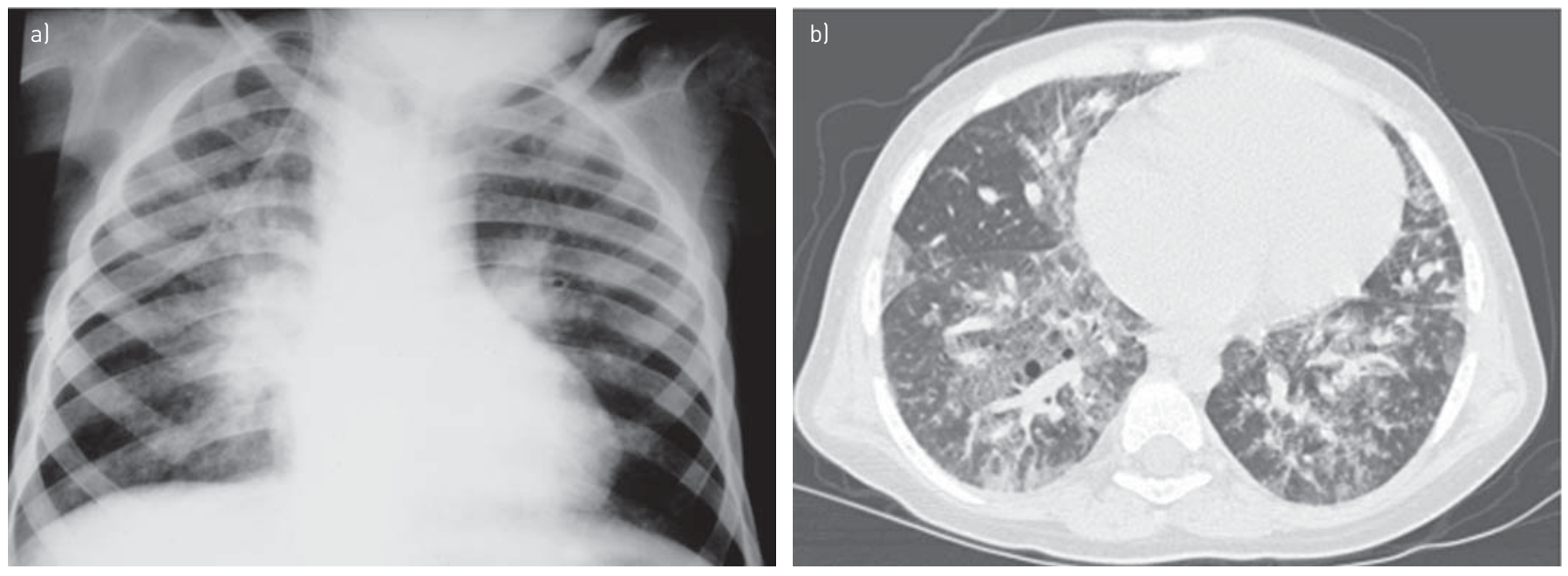

FIGURE 1 a) A 2-year-old male with Niemann-Pick disease type A. Chest radiograph shows multiple airspace consolidations in right lower and middle lobes, and diffuse reticulonodular infiltrate. b) A 7-year-old male with Niemann-Pick disease type C and NPC2 mutation. High-resolution computed tomography shows bilateral patchy airspace ground-glass opacities with diffuse thickening of the interlobular septa. 
dyspnoea, or pulmonary haemorrhage culminating in fatal respiratory insufficiency, were children with a severe Gaucher disease course [38, 41]. Nevertheless, chest radiographs or computed tomography (CT) abnormalities were also described in type I adults [42, 43]. KerEM et al. [44] reported that Gaucher disease type I subjects with the "mild" genotype N370S and impaired lung function had a higher severity score index than those with normal pulmonary function. Younger subjects with different genotypes and more serious respiratory manifestations were not evaluated and, thus, the authors could not conclude that a genotype-phenotype correlation with regard to Gaucher disease lung disease exists. In a study of adults and adolescents with Gaucher disease type I, lung disease was clinically evident in $<5 \%$ of the cases, with main features including dyspnoea and exercise limitation that were not associated with lung function or lung imaging abnormalities [45]. A higher prevalence of respiratory disease was reported in children and adults with Gaucher disease type I and III from Italy [46]. In this population, pulmonary involvement appeared significantly more frequent in subjects who were homoallelic for the L444P mutation than in patients with other genotypes, with ILD being the principal feature. Gaucher disease patients with genotypes other than L444P/L444P did not show any radiological sign of lung damage.

Pulmonary involvement in Gaucher disease is multifaceted and due to several mechanisms. Gaucher cells can fill the alveolar spaces and/or the inter- and intralobular septa, leading to air space disease and/or ILD, respectively. Pulmonary vascular disease is probably more common than suspected. Pulmonary hypertension due to plexogenic arteriopathy and intrapulmonary shunts related to the hepatopulmonary syndrome have been described in the same individual [47], and are the probable cause of severe respiratory failure in Gaucher disease even in the absence of Gaucher cells in the lung [16, 48]. Splenectomy and female sex seem to be the most important risk factors for pulmonary hypertension in Gaucher disease [15]. Although capillary plugging by Gaucher cells may favour the development of pulmonary hypertension, it has also been hypothesised that a circulating vasoactive substance that bypasses the diseased liver may be responsible for it [16]. Finally, chronic hypoxaemia secondary to ILD, associated liver disease, long bone infection and fracture with pulmonary emboli may result in pulmonary hypertension [44]. Whatever the pathogenesis, digital clubbing is described as a common feature of pulmonary vascular disease in Gaucher disease.

In Gaucher disease, hepatosplenomegaly and spinal deformities progressively lead to small lung volumes and to changes of the pulmonary vascular bed with secondary hypoventilation due to limited diaphragmatic excursions. Increased lung surfactant phosphatidylcholine levels can lead to high susceptibility to respiratory infections in type I Gaucher disease [49]. Finally, in cases with predominant neurological involvement, aspiration pneumonia may occur because of swallowing disorders associated with neuromotor delay [36].

Given the importance of lung involvement in Gaucher disease, it is essential that patients are referred to the pulmonary unit and that monitoring is scheduled at predetermined intervals [50]. It was proposed that the Gaucher disease severity score should also include lung function and chest imaging findings [46, 51]. This would allow physicians to consider pulmonary status as an outcome parameter for evaluating the effects of treatment in Gaucher disease.

\section{Fabry disease}

In Fabry disease, an X-linked error of glycosphingolipid catabolism caused by a partial or total defect of $\alpha$-galactosidase A, deposition of glycosphingolipids was also reported in the lung [1]. Recurrent cough due to chronic bronchitis, wheezing, dyspnoea at rest with alveolar capillary block, and exercise intolerance seem more frequent in adults than in children [52-54]. Nevertheless, in older hemizygotes, pulmonary function tests show mild-to-moderate obstruction with reduced diffusing capacity in the absence of symptoms $[55,56]$.

\section{Farber lipogranulomatosis}

In patients with Farber lipogranulomatosis, which is due to a deficiency of acid ceramidase activity that results in the deposition of ceramide in the heart, lymph nodes and airways, severe pulmonary infections are the usual cause of death [1]. The characteristic features of Farber disease type I in paediatrics include a hoarse cry progressing to aphonia, dysphagia and respiratory difficulties, possibly leading to fatal failure [57-59].

\section{Hermansky-Pudlak syndrome}

Hermansky-Pudlak syndrome is caused by mutations in several genes that encode proteins regulating the biogenesis or transport of lysosome-related organelles and lysosomes in specialised secretory cells, including type II pneumocytes [60]. Lysosomal ceroid-like lipofuscin accumulates in the reticuloendothelial system, particularly in alveolar macrophages. Among the different types, Hermansky-Pudlak syndrome-1 is the subtype most frequently associated with increased lung disease risk [61, 62]. Patients with HermanskyPudlak syndrome, especially females, may develop pulmonary fibrosis with excessive inflammatory cells and lipofuscin ceroid within the alveolar macrophages [63]. Pulmonary disease, usually starting in adult life, presents with chronic nonproductive cough, progressive dyspnoea and restrictive pattern [64]. 
Reticulonodular interstitial pattern, perihilar fibrosis, pleural thickening on chest radiographs, septal thickening, ground-glass opacities and peribronchovascular thickening on HRCT correlate with decreasing vital capacity [64].

\section{Wolman disease}

Wolman disease is a rare, autosomal recessive disorder characterised by a deficient activity of lysosomal acid lipase that results in large accumulation of cholesteryl esters and triglycerides in the liver, spleen, lymph nodes, lung, adrenal cortex and small bowel [65].The lungs of patients with Wolman disease may contain variable numbers of foam cells in the alveoli [66]. The extensive atherosclerosis suggests that the deficiency of an enzyme involved in lipid metabolism may lead to accelerated atherosclerosis. In addition, these patients are considered at risk for the development of significant pulmonary hypertension [9].

\section{Disorders of amino acids transport and metabolism}

\section{Lysinuric protein intolerance}

Lysinuric protein intolerance, an autosomal recessive transport defect of the cationic amino acids (i.e. lysine, arginine and ornithine), is caused by mutations in the SLC7A7 gene, which encodes the y(+)LAT-1 protein, the catalytic light chain subunit of a complex belonging to the heterodimeric amino acid transporter family $[67,68]$. The defect is expressed in the intestine and renal tubules, and probably in hepatocytes and skin fibroblasts. Most clinical manifestations of lysinuric protein intolerance (i.e. failure to thrive, gastrointestinal disease, bone-marrow abnormalities, osteoporosis and renal disease) have been well characterised and are related to the metabolic derangement [69]. Treatment with a low-protein diet supplemented with citrulline, which is not affected by the transport defect, produces clinical improvement.

The majority of lysinuric protein intolerance patients have been described in Finland and in southern Italy $[69,70]$. Among the clinical manifestations, pulmonary disease represents a rare, but life-threatening, complication sometimes leading to fatal respiratory insufficiency that may begin with acute or subacute features.

Respiratory manifestations of lysinuric protein intolerance range from radiological signs of ILD with diffuse or localised reticulo-nodular infiltrates and/or thickening of the inter-/intralobular walls septa [71], in the absence of overt clinical symptoms, to severe lung disease [72, 73].

ILD may precede the acute clinical phase of lysinuric protein intolerance $[72,74]$, and although no effective treatment for it exists at present, it is important to unequivocally assess pulmonary involvement early in the disease process. Severe respiratory insufficiency was the presenting feature of a young male in whom the lung biopsy showed ILD with cholesterol casts around and within macrophages and alveolar cells [75]. The majority of symptomatic patients present with moderate-to-severe wheezing, susceptibility to respiratory infections that cause recurrent to chronic cough, progressive poor tolerance to efforts and, sometimes, mildto-moderate haemoptysis [72]. At this stage of the disease, BAL shows a high number of macrophages with significantly more multilamellar structures than control cells [76]. Furthermore, alveolar activation and subclinical alveolitis have been associated with lysinuric protein intolerance lung disease [65].

One of the most severe complications of lysinuric protein intolerance is PAP [71-73, 77]. PAP is characterised by excessive surfactant accumulation within the alveolar spaces, probably caused by an imbalance between production of surfactant-like material by type II pneumocytes and clearance by alveolar macrophages [78, 79]. Immunological abnormalities, including decreased IgA and autoimmunity, were previously demonstrated in PAP, but were not associated with lysinuric protein intolerance [80]. However, the report of PAP in siblings suggests that genetic factors are important, or that some of the cases may also have lysinuric protein intolerance [81]. In lysinuric protein intolerance, the clinical picture of PAP is dominated by moderate-to-severe manifestations that may progress to severe and often fatal respiratory failure [69]. Bilateral infiltrates are typically present on chest radiography, and HRCT reveals ground-glass opacities and airspace consolidation with interlobular septal thickening in the characteristic diffuse or localised "crazy paving" pattern (fig. 2). The pathogenesis of lysinuric protein intolerance lung disease is still obscure. A case report of a young child with lysinuric protein intolerance and progressive respiratory failure due to PAP who underwent heart-lung transplant and died with recurrent PAP in the transplanted lung, led to the hypothesis that the defective transport of the cationic amino acids is also present in the alveolar macrophages [82]. This would justify the increased availability of arginine and, consequently, an increased synthesis of nitric oxide that, in the presence of inflammatory cytokines and endotoxins, may result in progressive lung disease $[83,84]$. This hypothesis was confirmed in a study which reported that the transport system of $\mathrm{y}(+)$ LAT-1 in the BAL monocytes and alveolar macrophages from an adult with lysinuric protein intolerance and PAP is impaired [85]. Patients with lysinuric protein intolerance do not present high levels of circulating granulocyte-macrophage colony-stimulating factor (GM-CSF) autoantibodies $[85,86]$, thus suggesting that the GM-CSF signalling pathway is unaltered in lysinuric protein 


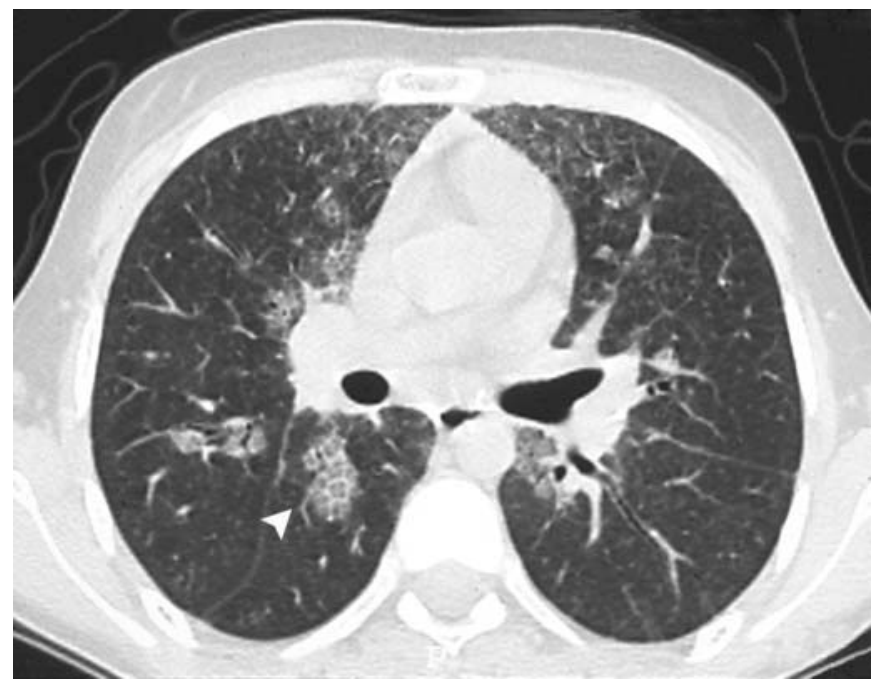

FIGURE 2 A 15-year-old female with lysinuric protein intolerance. Highresolution computed tomography shows ground-glass opacities with localised pulmonary alveolar proteinoisis-like pattern (crazy paving pattern, arrowhead).

intolerance. This finding, combined with the demonstration that SLC7A7/y+LAT1 mutations lead to a defective phenotype of macrophages [86], support a fundamental role of these cells in the development of PAP in lysinuric protein intolerance.

While it is still a matter of debate as to whether citrulline is beneficial or even worsens the clinical course of lysinuric protein intolerance [69], unfortunately respiratory complications of lysinuric protein intolerance do not seem to be influenced by early treatment or citrulline supplementation [69]. Despite this, the age at onset of respiratory symptoms seems critical for the definition of lung disease severity, and patients with symptoms and signs in the first decade of life generally have worse pulmonary prognosis [72]. PAP is less common in children with lysinuric protein intolerance than in adults, but the course seems more aggressive in childhood. For this reason parents of affected children, and adult patients themselves, should be repeatedly warned of pulmonary symptoms.

\section{Glycogenoses}

Glycogen storage diseases are disorders affecting glycogen metabolism [1]. Respiratory manifestations were observed primarily in glycogenosis type I and type II [87]. Pulmonary hypertension is a rare and severe complication of type Ia (due to glucose-6-phosphatase deficiency) and type Ib (due to glucose-6-phosphate translocase deficiency) [5,6], the mechanism of which is unclear [88]. It has been postulated that vasoconstrictive amines such as serotonin, a pulmonary vasoconstrictor and growth factor for vascular smooth muscle cells that is stored in platelets, could favour the development of pulmonary hypertension in type Ia glycogenosis [88].

Type II glycogenosis (Pompe disease) is caused by $\alpha$-glucosidase deficiency [89]. According to the age at symptoms onset, three forms of disease were described. 1) The most severe form, diagnosed in infants between 3 and 5 months of age (floppy babies) during the assessment of a respiratory infection, cardiomegaly or severe generalised hypotonia, in which the progressive and debilitating musculoskeletal, respiratory and cardiac symptoms result in early death. 2) The non-classical infantile form, with onset between the first and second year of life, characterised by recurrent respiratory infections and a variable prognosis. 3) The late-onset form, which can occur at any age starting from childhood, with slow muscular involvement, absence of cardiac involvement and less severe outcome than the classical form [90]. Respiratory insufficiency is a serious threat to patients with Pompe disease in infancy, as well as in late childhood or adolescence [91]. Respiratory manifestations in patients with Pompe disease do not primarily involve the airways. The basic issue is excessive diaphragmatic weakness and subsequent peripheral alveolar hypoventilation. The occurrence of progressive, sometimes fatal, respiratory failure is primarily due to the inability of the respiratory muscles to generate normal levels of pressure and airflow during in- and expiration. These events significantly impair the removal of airway secretions and, therefore, recurrent infections, even pneumonia and atelectasis, which can eventually result in severe respiratory failure, were reported [90]. Respiratory symptoms may occur during the night, with apnoea or hypoventilation worsening the clinical course [92]. In a prospective study of children and adults with Pompe disease, $74 \%$ of all patients, including $53 \%$ of the children, had some degree of functional impairment, with male subjects, patients with severe muscle weakness and those with advanced disease duration appearing most at risk of 
mechanical ventilation [93]. Pellegrini et al. [94] did not find any correlation between the age of 29 patients with late-onset Pompe disease and the presence, in some cases, of severe respiratory insufficiency without severe limb girdle muscle weakness, and highlighted that respiratory function should be monitored independently from the degree of peripheral muscle weakness.

\section{Mucopolysaccharidoses}

MPS are caused by a deficiency of one of the lysosomal enzymes needed for the glycosaminoglycan (GAG) breakdown pathway [1]. These disorders compose a heterogeneous group of nine forms characterised by GAG accumulation in several organs and tissues. The hallmarks of most phenotypes derive from multiple anatomical abnormalities including: facial dysmorphism with coarse face, macrocephaly, thick lips, hypertrophic gums and enlarged tongue; dysostosis and joint motion limitation; hepatosplenomegaly; and cardiovascular anomalies [95]. Mental retardation is not common to all MPS.

Cardiorespiratory involvement is an important cause of morbidity and mortality, particularly in some types of MPS [96]. The GAG deposition in the upper airways, which become increasingly narrowed, is probably a major determinant of symptoms in Hurler (MPS type I), Hunter (MPS type II), Morquio (MPS type IV) and Maroteaux-Lamy (MPS type VI) syndromes [95, 97-99]. In the vast majority of patients, noisy breathing, oral snoring and even severe OSAS dominate the clinical picture, and recurrent airway infections are reported at all ages [97, 99-104]. Severe respiratory problems that significantly contribute to premature mortality were reported in MPS type I, II, IV and VI [104].

Upper airway obstruction of MPS is multifaceted [95, 97]. An enlarged tongue and bone craniofacial abnormalities, namely micrognathia, result in predominant nasal breathing and oral snoring [97, 105]. Upper airway obstruction and OSAS, combined with thoracic cage deformity and tracheal distortion due to shortened spinal height, lead to frequent total airway collapse, as reported in adults with Morquio's syndrome $[102,106]$.

GAG deposition in the pharynx, larynx and trachea may lead to the need for proper airway management, from intubation to tracheostomy tube placement. Ultimately, this results in potentially life-threatening anaesthetic complications and in an increased anaesthetic risk [107]. During sedation, cervical spine instability may complicate the laryngotracheal intubation and tracheotomy often represents an obliged choice for avoiding fatal respiratory failure [108]. This might result in delay or cancellation of general anaesthesia for surgical interventions, such as central lines, adenotonsillectomy, cervical decompression or orthopedic interventions $[109,110]$. The erratic deposits of mucopolysaccharides throughout the trachea should be taken into account when decisions to stent the airway are made. Patients should be managed by anaesthesiologists familiar with MPS who define appropriate evaluation, and also anticipate potential postoperative problems. Table 2 summarises the basic defects, main clinical features and respiratory manifestations of selected inherited metabolic diseases.

\section{Approach to diagnosis and treatment of respiratory manifestations of inherited metabolic diseases \\ Diagnosis}

The presentation of respiratory manifestations associated with inherited metabolic diseases differs between children and adults. Medical history should look at major presenting features, and physical examination should include vital signs, body weight and height measures, as well as upper and lower airway examination (table 3). As far as the diagnostic investigations are concerned, they should be discussed in multidisciplinary sessions including a pulmonologist, hopefully supported by physicians with special skills in the management of airway disease such as radiologists, bronchoscopists, anaesthesiologists and ear, nose and throat (ENT) specialists [107, 108, 111-113]. The choice should take into account the individual characteristics of the patient such as age and level of cooperation, as well as type and severity of respiratory manifestations.

Chest imaging and arterial blood gas analysis are mandatory in the presence of suspected or overt respiratory manifestations, either to define the type and extent of the lesion or to document the onset of compensated (hypoxaemia alone) or uncompensated (in the presence of hypercapnia) respiratory failure. Among imaging techniques, chest radiography is the first-line examination to confirm or exclude the pulmonary involvement. Since ILD is frequent, chest HRCT, possibly using low-dose CT in children, is recommended to define the extent and severity of lung changes [114]. Table 4 summarises the major chest imaging characteristics in specific inherited metabolic diseases. Bronchoscopy and BAL can be added to the diagnostic work-up in the presence of interstitial pneumonia or segmental/lobar atelectasis [115], used to collect lower airways secretions to be cultured and/or for confirming PAP [72, 73, 82, 116]. Lung biopsy was performed in three children with recurrent severe lower airways infections of unknown aetiology, thus allowing the diagnosis of Niemann-Pick disease type B [117]. 
TABLE 2 Basic defects, and clinical and respiratory features of selected inherited metabolic diseases

\begin{tabular}{|c|c|c|c|c|}
\hline Disorder and subtype & Basic defect & Gene & Clinical features & Respiratory manifestations \\
\hline \multicolumn{5}{|l|}{ Niemann-Pick disease } \\
\hline Type A & $\begin{array}{l}\text { Acid sphingomyelinase } \\
\text { deficiency }\end{array}$ & SMPD1 & $\begin{array}{l}\text { Onset in infancy, retinopathy hepatosplenomegaly } \\
\text { and rapidly progressive neurological deterioration }\end{array}$ & $\begin{array}{l}\text { Recurrent bronchitis or aspiration pneumonia } \\
\text { culminating in life-threatening or fatal events }\end{array}$ \\
\hline Type B & $\begin{array}{l}\text { Acid sphingomyelinase } \\
\text { deficiency }\end{array}$ & SMPD1 & $\begin{array}{l}\text { Onset in childhood, hepatosplenomegaly, growth } \\
\text { retardation and mild clinical course }\end{array}$ & $\begin{array}{c}\text { Mild dyspnoea on exertion, interstitial lung } \\
\text { disease, and severe and fatal respiratory } \\
\text { insufficiency }\end{array}$ \\
\hline Type C & $\begin{array}{l}\text { Abnormal trafficking of } \\
\text { sphingolipids }\end{array}$ & NPC1 and NPC2 & $\begin{array}{l}\text { Variable age at onset, hepatosplenomegaly, progressive } \\
\text { neurological involvement and subacute clinical course }\end{array}$ & $\begin{array}{l}\text { Interstitial lung disease, aspiration pneumonia, } \\
\text { and pulmonary alveolar proteinosis with } \\
\text { respiratory insufficiency (in NPC2 genotype) }\end{array}$ \\
\hline \multicolumn{5}{|l|}{ Gaucher disease } \\
\hline Type 1 & $\begin{array}{l}\beta \text {-glucocerebrosidase } \\
\text { deficiency }\end{array}$ & $\begin{array}{l}\text { GBA (high prevalence of } \\
\text { the N370S mutation) }\end{array}$ & $\begin{array}{l}\text { Non-neuronopathic form, hepatosplenomegaly, } \\
\text { thrombocytopenia, and bone disease }\end{array}$ & $\begin{array}{l}\text { Ventilatory dysfunction, recurrent respiratory } \\
\text { infections and pulmonary hypertension }\end{array}$ \\
\hline Type 2 & $\begin{array}{l}\beta \text {-glucocerebrosidase } \\
\text { deficiency }\end{array}$ & $\begin{array}{l}\text { GBA (high prevalence of } \\
\text { L444P/L444P and other } \\
\text { "neuronopathic" mutations) }\end{array}$ & $\begin{array}{c}\text { Acute neurological form, early onset, rapidly } \\
\text { progressing brainstem dysfunction and } \\
\text { hepatosplenomegaly }\end{array}$ & $\begin{array}{l}\text { Ventilatory dysfunction, aspiration pneumonia, } \\
\text { and increased risk of interstitial lung disease in } \\
\text { homozygotes for L444P mutation }\end{array}$ \\
\hline Type 3 & $\begin{array}{l}\beta \text {-glucocerebrosidase } \\
\text { deficiency }\end{array}$ & $\begin{array}{l}\text { GBA (high prevalence of } \\
\text { L444P/L444P mutation) }\end{array}$ & $\begin{array}{c}\text { Subacute progressive encephalopathy loculomotor } \\
\text { apraxia, epilepsy and ataxial and systemic } \\
\text { manifestations as in type } 1\end{array}$ & $\begin{array}{c}\text { Ventilatory dysfunction, aspiration pneumonia, } \\
\text { and increased risk of interstitial lung disease in } \\
\text { homozygotes for L444P mutation }\end{array}$ \\
\hline Fabry disease & $\alpha$-galactosidase A & GLA & $\begin{array}{l}\text { Renal and cardiac insufficiency, neuropathic pain, } \\
\text { angiokeratoma and premature stroke }\end{array}$ & $\begin{array}{l}\text { Wheezing, chronic bronchitis and exercise } \\
\text { intolerance }\end{array}$ \\
\hline $\begin{array}{l}\text { Farber } \\
\quad \text { lipogranulomatosis }\end{array}$ & Acid ceramidase & ASAH1 & $\begin{array}{l}\text { Joint swelling, subcutaneous nodules and delayed } \\
\text { psychomotor development }\end{array}$ & $\begin{array}{c}\text { Aphonia, lower airways infections and fatal } \\
\text { respiratory failure }\end{array}$ \\
\hline $\begin{array}{l}\text { Hermansky-Pudlak } \\
\text { syndrome }\end{array}$ & $\begin{array}{l}\text { Disrupted biogenesis of } \\
\text { lysosome-related } \\
\text { organelles }\end{array}$ & HPS1 & $\begin{array}{l}\text { Oculocutaneous albinism, bleeding, diathesis, } \\
\text { neutropenia and granulomatous colitis }\end{array}$ & Pulmonary fibrosis and interstitial lung disease \\
\hline Wolman disease & $\begin{array}{l}\text { Deficient activity of } \\
\text { lysosomal acid lipase }\end{array}$ & LIPA & $\begin{array}{l}\text { Hepatosplenomegaly, gastrointestinal symptoms and } \\
\text { calcified adrenal glands }\end{array}$ & Pulmonary hypertension \\
\hline $\begin{array}{l}\text { Lysinuric protein } \\
\text { intolerance }\end{array}$ & $\begin{array}{l}\text { Defective cationic amino } \\
\text { acid transport }\end{array}$ & SLC7A7 & $\begin{array}{l}\text { Failure to thrive, osteoporosis, bone marrow } \\
\text { anomalies, hepatosplenomegaly, hyperammonaemia, } \\
\text { kidney disease and gastrointestinal symptoms }\end{array}$ & $\begin{array}{l}\text { Wheezing, respiratory infections, exercise } \\
\text { intolerance, haemoptysis, interstitial lung } \\
\text { disease, and pulmonary alveolar proteinosis }\end{array}$ \\
\hline \multicolumn{5}{|l|}{ Glycogenoses } \\
\hline Type la & Glucose-6 phosphatase & G6PC & $\begin{array}{l}\text { Hepatomegaly, growth retardation, osteopenia, } \\
\text { full-cheeked round face, nephromegaly and } \\
\text { platelet dysfunction }\end{array}$ & Pulmonary hypertension \\
\hline Type lb & $\begin{array}{l}\text { Glucose- } 6 \text { phosphate } \\
\text { translocase }\end{array}$ & SLC37A4 & As type la, neutropenia and neutrophil dysfunction & Pulmonary hypertension \\
\hline Type II & $\alpha$-glucosidase & GAA & $\begin{array}{l}\text { Infantile onset: hepatomegaly, feeding difficulties, } \\
\text { cardiomegaly and muscle weakness } \\
\text { Juvenile and adult-onset: muscle weakness and no } \\
\text { cardiac disease }\end{array}$ & $\begin{array}{l}\text { Alveolar hypoventilation and risk of } \\
\text { respiratory failure }\end{array}$ \\
\hline Mucopolysaccharidoses & $\begin{array}{l}\text { Lysosomal enzymes in the } \\
\text { glycosamino-glycan } \\
\text { breakdown pathway }\end{array}$ & $\begin{array}{l}\text { I: IDUA; II: IDS; IIIA: SGSH; } \\
\text { IIIB: NAGLU; IIIC: HGSNAT; } \\
\text { IIID: GNS; IVA: GALNS; IVB: } \\
\text { GLB1; VI: ARSB; VII: GUSB; } \\
\text { IX: HYAL1 }\end{array}$ & $\begin{array}{l}\text { Facial dysmorphisms, macrocephaly, dysostosis, } \\
\text { joint motion limitation, hepatosplenomegaly, } \\
\text { cardiac valve thickening, cardiomegaly and } \\
\text { mental retardation (not in all types) }\end{array}$ & $\begin{array}{l}\text { Type I, II, IV and VI: recurrent upper airway } \\
\text { infections, obstructive sleep apnoea } \\
\text { syndrome and severe respiratory failure }\end{array}$ \\
\hline
\end{tabular}

Swallowing function using video fluoroscopy should be monitored closely, particularly in subjects at risk of aspiration in the event of secondary airway aspiration [118].

Spirometry, lung volume determination and carbon monoxide diffusion provide substantial information about obstructive and/or restrictive patterns and alveolar gases impairment [119], but testing is limited to cooperating subjects. Upright vital capacity has been indicated as an important marker of diaphragmatic dysfunction in adults with Pompe disease [120]. Major reduction in exercise capacity was reported in glycogenosis type I [121] or in mitochondrial disorders [122]. Therefore, exercise testing using a treadmill or cycloergometry could be performed in cooperating patients with inherited metabolic disease-associated myopathy.

In inherited metabolic diseases and suspected OSAS the assessments based upon clinical history alone are generally inadequate $[105,123,124]$. Overnight polysomnography is the first-line procedure in MPS and suspected upper airways involvement [104]. Nasal endoscopy combined with upper airway CT or magnetic resonance imaging may provide useful additional information on the site of obstruction. In a study of MPS adults and children, CT scans revealed that the retropalatal and retroglossal spaces were significantly more reduced in patients with OSAS than in controls [113]. Polysomnography and upper airway imaging appeared more abnormal in the paediatric population than in adults with MPS, suggesting that children are at higher risk of airway obstruction. 
TABLE 3 Assessment of patients with inherited metabolic diseases and suspected respiratory manifestations

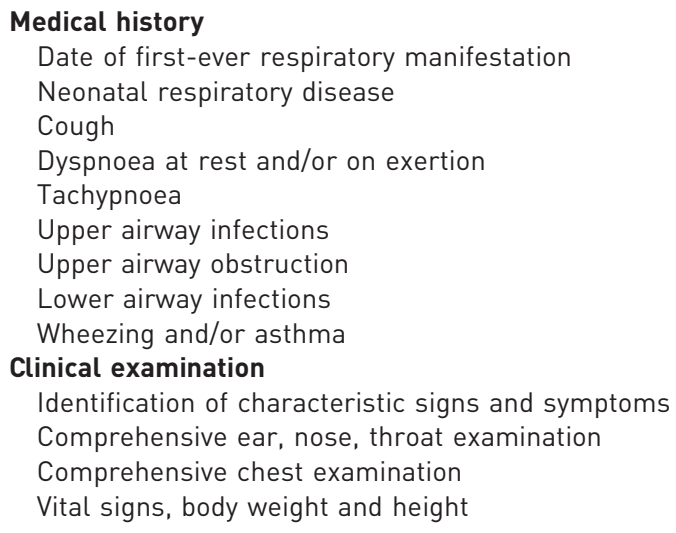

\section{Treatment}

General respiratory health maintenance therapy

In patients with inherited metabolic disease at risk of airway disease, specific interventions aimed at promoting and restoring the physiology of the airways are strongly recommended in the early phases of the disease to clear the airways, avoid infections and maintain adequate alveolar ventilation. Unfortunately, there are no controlled data from clinical trials to support the use of most of these interventions, which are generally prescribed on an empirical basis.

Accurate, daily airway toilet is the mainstay of the treatment. It includes aspiration of secretions after nasal lavage by micronised shower with saline or hypertonic saline solution. Not all patients with inherited metabolic disease will require regular daily chest physiotherapy, and the decision as to whether to prescribe it should be taken on an individual basis after considering the patient's respiratory symptoms and signs. In the presence of hypoxaemia, oxygen should also be administered at home after monitoring transcutaneous saturation. If bacterial airway infections are demonstrated, broad spectrum antibiotics should be prescribed based on sputum or deep throat culture. Systemic steroids are sometimes used in cases of severe respiratory symptoms, but based on empirical experience rather than on clear-cut evidence [125]. Adenotonsillectomy is included within the ascending ladder of MPS treatment modalities, and is considered crucial, at least for reducing upper airway obstruction [107].

With increased survival time and current advances in mechanical ventilation techniques, respiratory specialists are increasingly seeing paediatric and adult patients with inherited metabolic disease requiring noninvasive or invasive ventilation [93, 104]. Infants with Pompe disease frequently undergo mechanical ventilation, and the gap between diagnosis and ventilator use or death is reported to be 1-2 months [126, 127]. Mellies et al. [128] applied noninvasive ventilation to eight adults with late-onset Pompe disease and respiratory failure apparent from severe restrictive lung disease, nocturnal hypoxaemia and daytime hypercapnia. Despite further decrease of vital capacity and inspiratory muscle strength, noninvasive ventilation normalised oxygen saturation during sleep, daytime carbon dioxide tensions and symptoms [128].

Continuous positive airway pressure (CPAP), in which inspired air at elevated pressure is delivered through a specially designed mask, has proved to be effective for reducing OSAS in MPS [96]. High pressure nasal CPAP and supplemental oxygen should be considered in MPS cases in whom tracheostomy would have been very difficult due to the diffuse nature of the airway involvement [129]. Unfortunately, since mechanical ventilation with or without tracheostomy may be unsuccessful, fatal respiratory failure may occur at any age [106].

In lysinuric protein intolerance, high-dose oral steroids may slow down the progression of lung disease if started early, but might not be effective in all cases [73]. Treatment of lysinuric protein intoleranceassociated PAP with inhaled or subcutaneous GM-CSF has reported controversial results $[82,85,130]$. BAL has been reported to cure lysinuric protein intolerance-associated pulmonary symptoms within hours, even though frequent relapses have been described $[72,76]$. Ultimately, whole lung lavage is the best way to treat symptomatic PAP [72, 131]. 


\section{TABLE 4 Major chest imaging characteristics in specific inherited metabolic diseases}

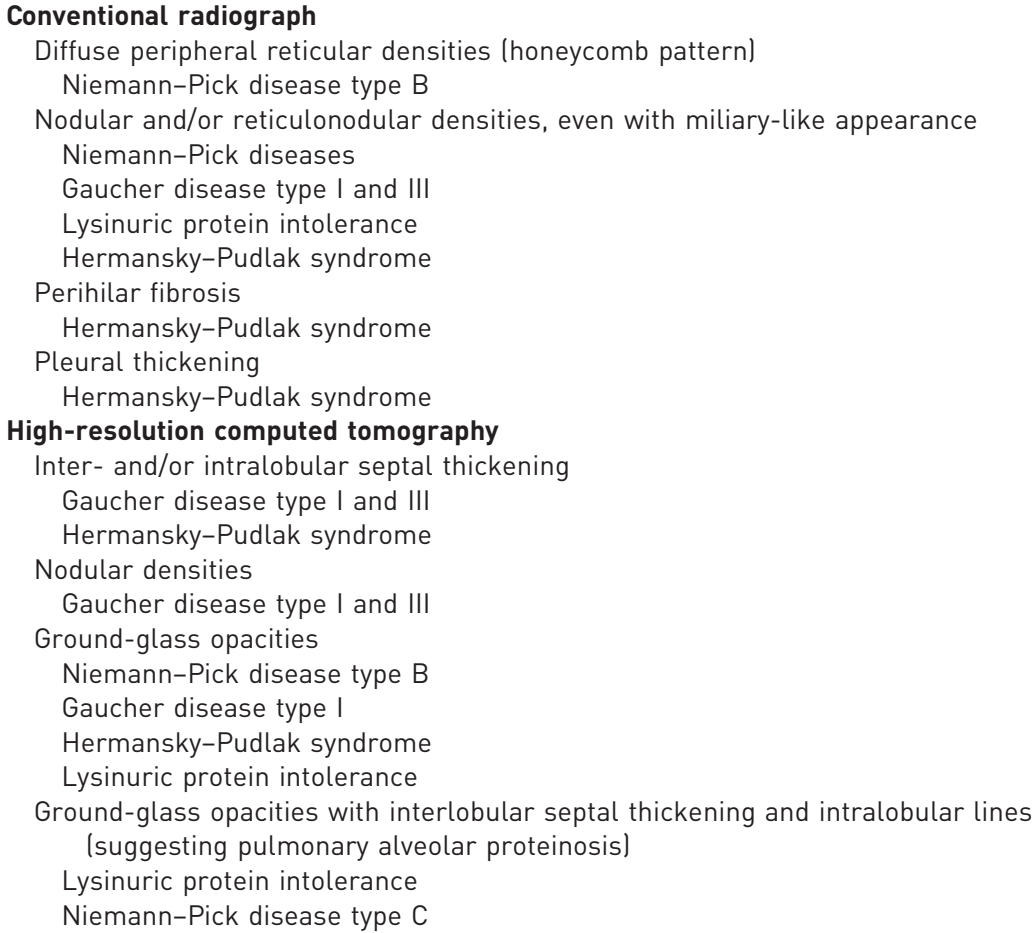

In Hermansky-Pudlak syndrome, the antifibrotic pirfenidone is the only symptomatic treatment that slows the progression of pulmonary fibrosis, especially in patients with residual lung function [132-134].

\section{Treatment}

Disease-specific therapy

In the past, the management of several inherited metabolic diseases was limited to support therapy of individual symptoms. The past decade has witnessed extraordinary innovation in the treatment of several inherited metabolic diseases with different approaches now available in pre-clinical and clinical testing, including enzyme replacement therapy (ERT), substrate reduction and haematopoietic stem cells transplantation [1]. More innovative strategies, such as pharmacological chaperone therapy and gene therapy, are under investigation for selected inherited metabolic diseases [135-137].

The effect of therapeutic interventions on the respiratory manifestations of specific inherited metabolic disease has been documented by several studies. A therapeutic role of BAL aimed at reducing the accumulation of abnormal metabolites within airways has been hypothesised in some inherited metabolic diseases, although its effectiveness is still under debate. In a patient with Niemann-Pick type C disease with recurrent pneumonia and chronic hypoxia, BAL significantly improved respiratory symptoms and ILD [34]. Other authors reported that the whole-lung lavage is a potentially useful modality of treatment for patients with Niemann-Pick disease type B and associated pulmonary involvement [35]. Conversely, an infant with the same disorder showed progressive respiratory failure after unilateral lung lavage, and died at age 15 months [26].

In Niemann-Pick disease type B and type C due to NPC2 gene mutation, haematopoietic stem cell transplantation can result in lung disease improvement [32, 138]. At present, the substrate reduction therapy with miglustat has been granted marketing authorisation in Europe and several other countries for specific treatment of neurological manifestations of Niemann-Pick disease. An observational study showed the efficacy of long-term treatment with miglustat in four children with Niemann-Pick disease type C to improve or prevent dysphagia and airway aspiration [118], confirming the beneficial effects on neurological disease [139].

In Gaucher disease, the effect of treatment on pulmonary disease depends on the case series and the type of Gaucher disease. In type III and I Gaucher disease, ERT causes some improvement of the respiratory 
TABLE 5 Effects of the most innovative therapeutic strategies on respiratory manifestations in lysosomal storage disorders

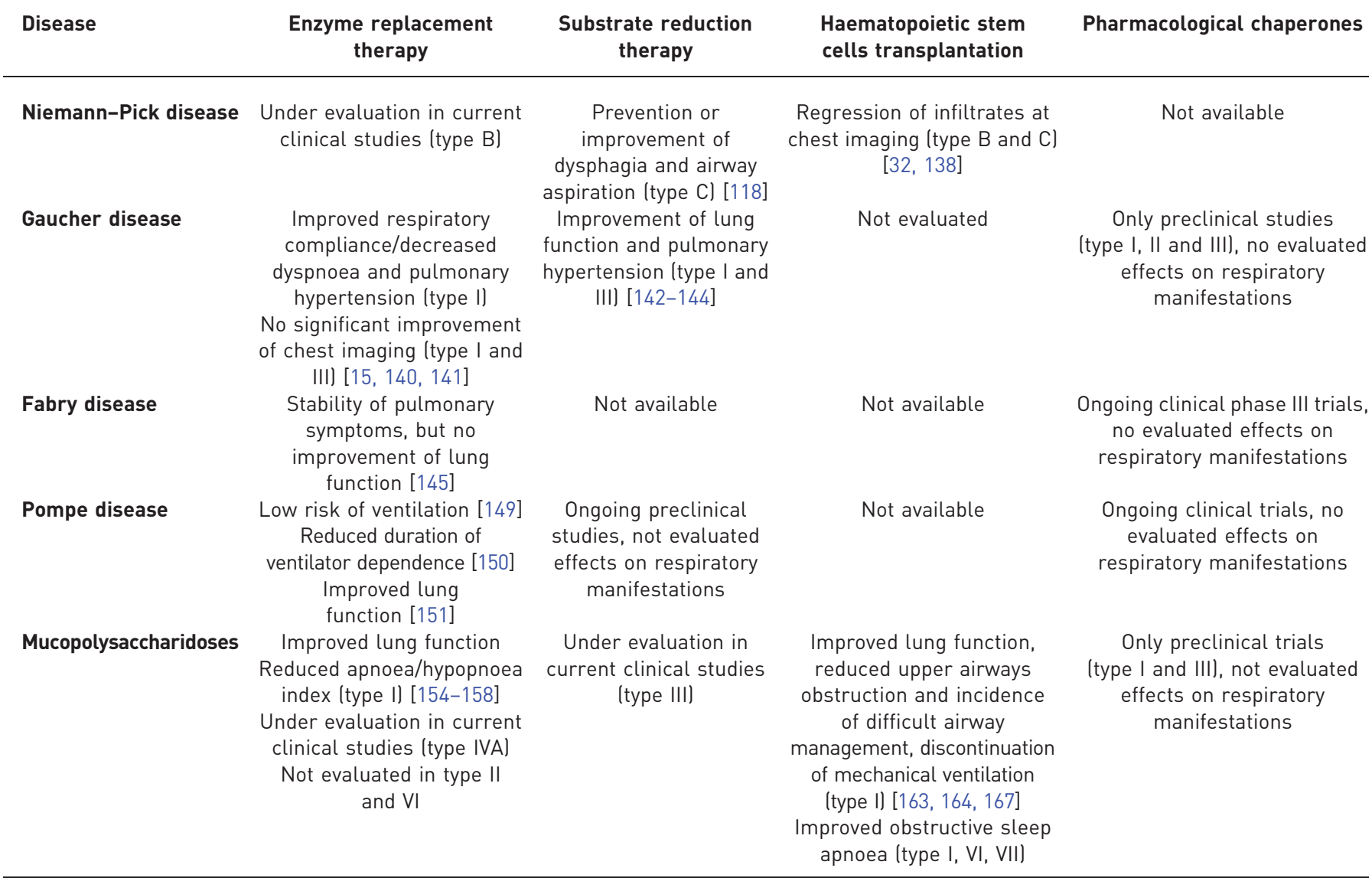

manifestations including pulmonary hypertension [15, 140, 141]. Conversely, miglustat seems more effective in patients with type III Gaucher disease whose respiratory symptoms or signs did not improve after acid $\beta$-glucosidase, and in cases with pulmonary hypertension who did not respond to ERT [142-144].

ERT with agalsidase- $\beta$ was found to stabilise symptoms of pulmonary Fabry disease in a female with dry, nonproductive cough and ILD, but did not improve total lung capacity due to pulmonary fibrosis [145].

Several studies of infants with Pompe disease demonstrated that early diagnosis and prompt treatment with recombinant $\alpha$-glucosidase is associated with improvement of main respiratory events, consistently reducing the need of mechanical ventilation [146-148]. In particular, treatment with recombinant $\alpha$-glucosidase in infants results in low risk of any type of ventilation or in reduced duration of ventilator dependence, and in a higher probability of being alive at age 36 months $[146,147] . \alpha$-glucosidase therapy also determines significant improvement of the 6-min walking test in late-onset Pompe's disease [149, 150], and of pulmonary function even in ventilator-dependent patients [151]. Indeed, the response of respiratory function to recombinant $\alpha$-glucosidase seems to be related to patients' age and the residual pulmonary function at baseline, with better outcomes reported when treatment is started within the first 6 months of life $[88,119]$. Taken together, these findings strongly suggest that early recognition of respiratory manifestations is crucial to achieve optimal therapeutic benefits for individuals with Pompe disease [119].

Some studies from our group demonstrated that the pharmacological chaperones improve the efficacy of ERT with recombinant $\alpha$-glucosidase in Pompe disease, and with recombinant $\alpha$-galactosidase A in Fabry disease $[135,137,152,153]$. Improving the efficacy of ERT has great clinical relevance in Pompe disease, as it is becoming increasingly evident that a synergistic effect of these treatments may result useful in patients responding poorly to ERT, but at present there are no studies on the effects on respiratory manifestations.

ERT is used in patients with MPS type I, II and VI [154-157], and beneficial effects on lung function and OSAS have been described [158-161]. A significant increase of forced vital capacity, probably resulting from chest wall impedance improvement to lung expansion, and a decrease of the apnoea/hypopnoea index, 
probably due to reduced GAGs in the upper airways, were demonstrated after $\alpha$-L-iduronidase in MPS I $[155,156,162]$. However, a recent chart review of MPS I found that patients receiving ERT still had a high incidence of airway problems (57\%) and a failed intubation rate of 3\%, while those treated early with bone marrow transplantation had lower incidence of airway complications (14\%), and no failed intubations [163].

Haematopoietic stem cells transplantation is effective in MPS types I, VI and VII, as it results in a dramatic reduction of obstructive airway symptoms [164]. When the procedure is performed at $<2$ years of age, engraftment after transplantation results in the improvement of sleep apnoea and upper airway disease and in the preservation of hearing [112, 164-166]. It also determines lung function improvement and discontinuation of mechanical ventilation in children with type I disease who did not respond to adenotonsillectomy $[112,167]$. Furthermore, the size of the oropharyngeal cavity, the appearance of the tongue and the visualisation of the larynx improve considerably after the procedure [168]. Thus, when instituted before 2 years of age, haematopoietic stem cell transplantation not only slows the progression of MPS-related respiratory disease, but also reduces the incidence of difficult airway management [112]. Table 5 summarises the effects of the most innovative therapeutic strategies in inherited metabolic diseases.

\section{Conclusions}

Over the past decades the molecular defect of several inherited metabolic diseases has been identified. New therapeutic strategies are currently available and have improved the life expectation for many patients with inherited metabolic diseases since some even offer the potential of permanent cure. Improvements in the quality and implementation of medical care for patients with inherited metabolic diseases would hopefully result in increased survival. Respiratory disease is an important issue for patients with inherited metabolic diseases. It may complicate the clinical course at any age, and therefore is the major contributor to morbidity and mortality at any age.

Appropriate care of the respiratory complications of inherited metabolic diseases is mandatory. The optimal integration of multiple skills in a team, including physicians with proven experience in the management of the inherited metabolic diseases and pulmonologists, ENT specialists, anaesthetists and radiologists, is ideal for improving the prognosis of the respiratory disease associated with inherited metabolic diseases. These specialists have an opportunity to play an integrated role in the multidisciplinary approach to the disease. Clinical suspicion, early recognition and prompt diagnosis of the respiratory disease associated to these challenging disorders is crucial, as outcomes of treatment in many cases appear time-sensitive, with better results being achieved when intervention is initiated at a younger age or before the diseases has progressed.

\section{References}

1 Scriver CR, Beaudet AL, Valle D, et al., eds. The Metabolic and Molecular Bases of Inherited Disease. 8th Edn. New York, McGraw-Hill, 2001.

2 Saudubray JM, Charpentier C. Clinical phenotypes: diagnosis/algorithms. In: Sriver CR, Beaudet AL, Sly WS, et al., eds. The Metabolic and Molecular Bases of Inherited Disease. 7th Edn. New York, McGraw-Hill, 1995; pp. 327-400.

3 Tokatli A, Coşkun T, Ozalp I, et al. The major presenting symptom in a biotinidase-deficient patient: laryngeal stridor. J Inherit Metab Dis 1992; 15: 281-282.

4 Menéndez Suso JJ, Del Cerro Marín MJ, Dorao Martínez-Romillo P, et al. Nonketotic hyperglycinemia presenting as pulmonary hypertensive vascular disease and fatal pulmonary edema in response to pulmonary vasodilator therapy. J Pediatr 2012; 161: 557-559.

5 Humbert M, Labrune P, Sitbon O, et al. Pulmonary arterial hypertension and type-I glycogen-storage disease: the serotonin hypothesis. Eur Respir J 2002; 20: 59-65.

6 Ueno M, Murakami T, Takeda A, et al. Efficacy of oral sildenafil in a beraprost-treated patient with severe pulmonary hypertension secondary to type I glycogen storage disease. Circ J 2009; 73: 1965-1968.

7 Labrune P, Zittoun J, Duvaltier I, et al. Haemolytic uraemic syndrome and pulmonary hypertension in a patient with methionine synthase deficiency. Eur J Pediatr 1999; 158: 734-739.

8 Belostotsky R, Seboun E, Idelson GH, et al. Mutations in DHDPSL are responsible for primary hyperoxaluria type III. Am J Hum Genet 2010; 87: 392-399.

9 Cagle PT, Ferry GD, Beaudet AL, et al. Pulmonary hypertension in an 18-year-old girl with cholesteryl ester storage disease (CESD). Am J Med Genet 1986; 24: 711-722.

10 Ozand PT, Rashed M, Gascon GG, et al. Unusual presentations of propionic acidemia. Brain Dev 1994; 16: 46-57.

11 Brandstetter Y, Weinhouse E, Splaingard ML, et al. Cor pulmonale as a complication of methylmalonic acidemia and homocystinuria (Cbl-C type). Am J Med Genet 1990; 36: 167-171.

Schapira AH. Mitochondrial disease. Lancet 2006; 368: 70-82.

13 Donadieu J, Beaupain B, Rety-Jacob F, et al. Respiratory distress and sudden death of a patient with GSDIb chronic neutropenia: possible role of pegfilgrastim. Haematologica 2009; 94: 1175-1177.

Nyhan WL. Disorders of purine and pyrimidine metabolism. Mol Genet Metab 2005; 86: 25-33.

15 Mistry PK, Sirrs S, Chan A, et al. Pulmonary hypertension in type 1 Gaucher's disease: genetic and epigenetic determinants of phenotype and response to therapy. Mol Genet Metab 2002; 77: 91-98.

16 Theise ND, Ursell PC. Pulmonary hypertension and Gaucher's disease: logical association or mere coincidence? Am J Pediatr Hematol Oncol 1990; 12: 74-76. 
Jardim C, Hoette S, Souza R. Contemporary issues in pulmonary hypertension. Eur Respir Rev 2010; 19: $266-271$. Desnick JP, Kim J, He X, et al. Identification and characterization of eight novel SMPD1 mutations causing types A and B Niemann-Pick disease. Mol Med 2010; 16: 316-321.

Schuchman EH. The pathogenesis and treatment of acid sphingomyelinase-deficient Niemann-Pick disease. J Inherit Metab Dis 2007; 30: 654-663.

Sleat DE, Wiseman JA, El-Banna M, et al. Genetic evidence for nonredundant functional cooperativity between NPC1 and NPC2 in lipid transport. Proc Natl Acad Sci USA 2004; 101: 5886-5891.

1 Vanier MT. Lipid changes in Niemann-Pick disease type C brain: personal experience and review of the literature. Neurochem Res 1999; 24: 481-489.

Garver WS, Francis GA, Jelinek D, et al. The National Niemann-Pick C1 disease database: report of clinical features and health problems. Am J Med Genet 2007; 143: 1204-1211.

Patterson MC, Hendriksz CJ, Walterfang M, et al. Recommendations for the diagnosis and management of Niemann-Pick disease type C: an update. Mol Genet Metab 2012; 106: 330-344.

Guillemot N, Troadec C, de Villemeur TB, et al. Lung disease in Niemann-Pick disease. Pediatr Pulmonol 2007; 42: 1207-1214.

Mendelson DS, Wasserstein MP, Desnick RJ, et al. Type B Niemann-Pick disease: findings at chest radiography, thin-section CT, and pulmonary function testing. Radiology 2006; 238: 339-345.

Uyan ZS, Karadağ B, Ersu R, et al. Early pulmonary involvement in Niemann-Pick Type B disease: lung lavage is not useful. Pediatr Pulmonol 2005; 40: 169-172.

7 McGovern MM, Aron A, Brodie SE, et al. Natural history of type A Niemann-Pick disease: possible endpoints for therapeutic trials. Neurology 2006; 66: 228-232.

Minai OA, Sullivan EJ, Stoller JK. Pulmonary involvement in Niemann-Pick disease: case report and literature review. Respir Med 2000; 94: 1241-1251.

Bonetto G, Scarpa M, Carraro S, et al. A 3-year-old child with abdominal pain and fever. Eur Respir J 2005; 26: 974-977.

McGovern MM, Wasserstein MP, Giugliani R, et al. A prospective, cross-sectional survey study of the natural history of Niemann-Pick disease type B. Pediatrics 2008; 122: 341-349.

Vanier MT. Niemann-Pick disease type C. Orphanet J Rare Dis 2010; 3: 5-16.

Hsu YS, Hwu WL, Huang SF, et al. Niemann-Pick disease type C (a cellular cholesterol lipidosis) treated by bone marrow transplantation. Bone Marrow Transplant 1999; 24: 103-107.

Griese M, Brasch F, Aldana VR, et al. Respiratory disease in Niemann-Pick type C2 is caused by pulmonary alveolar proteinosis. Clin Genet 2010; 77: 119-130.

Palmeri S, Tarugi P, Sicurelli F, et al. Lung involvement in Niemann-Pick disease type C1: improvement with bronchoalveolar lavage. Neurol Sci 2005; 26: 171-173.

5 Nicholson AG, Wells AU, Hooper J, et al. Successful treatment of endogenous lipoid pneumonia due to NiemannPick type B disease with whole lung lavage. Am J Respir Crit Care Med 2002; 165: 128-131.

Zimran A, Elstein D. Lipid storage diseases. In: Lichtman MA, Kipps T, Seligsohn U, et al., eds. Williams Hematology. 8th Edn. New York, McGraw-Hill; 2010: pp. 1065-1071.

Mistry PK. Genotype/phenotype correlations in Gaucher's disease. Lancet 1995; 346: 982-983.

Brady RO, Barton NE, Grabowski GA. The role of neurogenetics in Gaucher's disease. Arch Neurol 1993; 50: $1212-1224$.

9 Abrahamov A, Elstein D, Gross-Tsur V, et al. Gaucher's disease variant characterized by progressive calcification of heart valves and unique genotype. Lancet 1995; 346: 1000-1003.

Lee RE, Yousem SA. Frequency and type of lung involvement in patients with Gaucher disease. Lab Invest 1988; $58: 54$. Vellodi A, Ashworth M, Finnegan N, et al. Pulmonary hemorrhage in type 3 Gaucher disease: a case report. J Inherit Metab Dis 2010; 33: Suppl. 3, 329-331.

42 Schneider EL, Epstein CJ, Kaback MJ, et al. Severe pulmonary involvement in adult Gaucher's disease. Am J Med 1977; 63: 475-480.

3 Yassa NA, Wilcox AG. High-resolution CT pulmonary findings in adults with Gaucher's disease. Clin Imaging 1998; 22: 339-342.

4 Kerem E, Elstein D, Abrahamov A, et al. Pulmonary function abnormalities in type I Gaucher disease. Eur Respir J 1996; 9: 340-345.

5 Miller A, Brown LK, Pastores GM, et al. Pulmonary involvement in type 1 Gaucher disease: functional and exercise findings in patients with and without clinical interstitial lung disease. Clin Genet 2003; 63: 368-376.

Santamaria F, Parenti G, Guidi G, et al. Pulmonary manifestations of Gaucher disease: an increased risk for L444P homozygotes? Am J Respir Crit Care Med 1998; 157: 985-989.

7 Lo SM, Liu J, Chen F, et al. Pulmonary vascular disease in Gaucher disease: clinical spectrum, determinants of phenotype and long-term outcomes of therapy. J Inherit Metab Dis 2011; 34: 643-650.

8 Dawson A, Elias DJ, Rubenson D, et al. Pulmonary hypertension developing after alglucerase therapy in two patients with type I Gaucher's disease complicated by the hepatopulmonary syndrome. Ann Intern Med 1996; 125 : 901-904.

9 Buccoliero R, Palmeri S, Ciarleglio G, et al. Increased lung surfactant phosphatidylcholine in patients affected by lysosomal storage diseases. J Inherit Metab Dis 2007; 30: 983.

50 Cox TM, Aerts JM, Andria G, et al. The role of theiminosugar N-butyldeoxynojirimycin (miglustat) in the management of type I (non-neuronopathic) Gaucher disease: a position statement. J Inherit Metab Dis 2003; 26: 513-526.

1 Zimran A, Sorge J, Gross E, et al. Prediction of severity of Gaucher's disease by identification of mutations at DNA level. Lancet 1989; 2: 349-352.

Eng CM, Germain DP, Banikazemi M, et al. Fabry disease: guidelines for the evaluation and management of multiorgan system involvement. Genet Med 2006; 8: 539-548.

3 Bierer G, Kamangar N, Balfe D, et al. Cardiopulmonary exercise testing in Fabry disease. Respiration 2005; 72: 504-511.

54 Brown LK, Miller A, Bhuptani A, et al. Pulmonary involvement in Fabry disease. Am J Respir Crit Care Med 1997; 155: 1004-1010. 
, Fusenberg DM, Ferrans VI, Fulmer JD, et al. Chronic airflow obstruction in Fabry's disease. Am J Med 1980; 68: 898-905.

56 Bartimmo EE Jr, Guisan M, Moser KM. Pulmonary involvement in Fabry's disease: a reappraisal follow-up of a San Diego kindred and review of literature. Am J Med 1972; 53: 755-764.

57 Samuelsson K, Zetterstrom R. Ceramides in a patient with lipogranulomatosis (Farber's disease) with chronic course. Scand J Clin Lab Invest 1971; 27: 393-405.

58 Pavone L, Moser HW, Mollica F, et al. Farber's lipogranulomatosis: ceramidase deficiency and prolonged survival in three relatives. Johns Hopkins Med J 1980; 147: 193-196.

59 Barrier H, Gillot F. La lipogranulomatose de Farber [Farber lipogranulomatosis]. Nouv Press Med 1973; 2: 767-770.

60 Pierson DM, Ionescu D, Qing G, et al. Pulmonary fibrosis in Hermansky-Pudlak syndrome. A case report and review. Respiration 2006; 73: 382-395.

61 Oh J, Bailin T, Fukai K, et al. Positional cloning of a gene for Hermansky-Pudlak syndrome, a disorder of cytoplasmic organelles. Nat Genet 1996; 14: 300-306.

62 Kobashi Y, Yoshida K, Miyashita N, et al. Hermansky-Pudlak syndrome with interstitial pneumonia without mutation of HSP1 gene. Intern Med 2005; 44: 616-621.

63 Young LR, Gulleman PM, Bridges JP, et al. The alveolar epithelium determines susceptibility to lung fibrosis in Hermansky-Pudlak syndrome. Am J Respir Crit Care Med 2012; 186: 1014-1024.

64 Avila NA, Brantly M, Premkumar A, et al. Hermansky-Pudlak syndrome: radiography and CT of the chest compared with pulmonary function tests and genetic studies. AJR Am J Roentgenol 2002; 179: 887-892.

65 Abramov A, Schorr S, Wolman M. Generalized xanthomatosis with calcified adrenals. Am J Dis Child 1956; 91: 282-286.

66 Marshall WC, Ockenden BC, Fosbrooke AS, et al. Wolman's disease: a rare lipidosis with adrenal calcification. Arch Dis Child 1968; 44: 331.

67 Sperandeo MP, Bassi MT, Riboni M, et al. Structure of the SLC7A7 gene and mutational analysis of patients affected by lysinuric protein intolerance. Am J Hum Genet 2000; 66: 92-99.

68 Sperandeo MP, Andria G, Sebastio G. Lysinuric protein intolerance: update and extended mutation analysis of the SLC7A7 gene. Hum Mutat 2008; 29: 14-21.

69 Sebastio G, Sperandeo MP, Andria G. Lysinuric protein intolerance: reviewing concepts on a multisystem disease. Am J Med Genet C Semin Med Genet 2011; 157: 54-62.

70 Tringham M, Kurko J, Tanner L, et al. Exploring the transcriptomic variation caused by the Finnish founder mutation of lysinuric protein intolerance (LPI). Mol Genet Metab 2012; 105: 408-415.

71 Santamaria F, Parenti G, Guidi G, et al. Early detection of lung involvement in lysinuric protein intolerance: role of high-resolution computed tomography and radioisotopic methods. Am J Respir Crit Care Med 1996; 153: 731-735.

72 Parto K, Svedstrom E, Majurin ML, et al. Pulmonary manifestations in lysinuric protein intolerance. Chest 1993; 104: 1176-1182.

73 DiRocco M, Garibotto G, Rossi GA, et al. Role of haematological, pulmonary and renal complications in the longterm prognosis of patients with lysinuric protein intolerance. Eur J Pediatr 1993; 152: 437-440.

74 Parenti G, Sebastio G, Strisciuglio P, et al. Lysinuric protein intolerance characterized by bone marrow abnormalities and severe clinical course. I Pediatr 1995; 126: 246-251.

75 Kerem E, Elpelg ON, Shalev RS, et al. Lysinuric protein intolerance with chronic interstitial lung disease and pulmonary cholesterol granulomas at onset. J Pediatr 1993; 123: 275-278.

76 Parto K, Maki J, Pelliniemi LJ, et al. Abnormal pulmonary macrophages in lysinuric protein intollerance. Ultrastructural, morphometric, and X-ray microanalytic study. Arch Pathol Lab Med 1994; 118: 536-541.

77 Parto K, Kallajoki M, Aho H, et al. Pulmonary alveolar proteinosis and glomerulonephritis in lysinuric protein intolerance: case reports and autopsy findings of four pediatric patients. Hum Pathol 1994; 25: 400-407.

Trapnell BC, Whitsett JA, Nakata K. Pulmonary alveolar proteinosis. N Engl J Med 2003; 349: 2527-2539. Borie R, Danel C, Debray MP, et al. Pulmonary alveolar proteinosis. Eur Respir Rev 2011; 20 : 98-107.

Webster JR Jr, Battifora H, Furey C, et al. Pulmonary alveolar proteinosis in two siblings with decreased immunoglobulin A. Am J Med 1980; 69: 786-789.

81 Simell O. Lysinuric protein intolerance and other cationic aminoaciduries. In: Scriver CR, Beaudet AL, Valle D, et al, eds. The Metabolic and Molecular Bases of Inherited Disease. 8th Edn. New York, McGraw-Hill, 2001; pp. 4933-4956.

82 Santamaria F, Brancaccio G, Parenti G, et al. Recurrent fatal pulmonary alveolar proteinosis after heart-lung transplantation in a child with lysinuric protein intolerance. J Pediatr 2004; 145: 268-272.

83 Mills CD. Macrophage arginine metabolism to ornithine/urea or nitric oxide/citrulline: a life or death issue. Crit Rev Immunol 2001; 21: 399-425.

84 Mannucci L, Emma F, Markert M, et al. Increased NO production in lysinuric protein intolerance. J Inherit Metab Dis 2005; 28: 123-129.

85 Barilli A, Rotoli BM, Visigalli R, et al. In lysinuric intolerance system $\mathrm{y}+\mathrm{L}$ activity is defective in monocytes and GM-CSF-differentiated macrophages. Orphanet J Rare Dis 2010; 5: 32.

86 Barilli A, Rotoli BM, Visigalli R, et al. Impaired phagocytosis in macrophages from patients affected by lysinuric protein intolerance. Mol Genet Metab 2012; 105: 585-589.

87 Chen YT. Glycogen storage diseases. In: Scriver CR, Beaudet AL, Valle D, et al., eds. The Metabolic and Molecular Bases of Inherited Disease. 8th Edn. New York, McGraw-Hill, 2001; pp. 1521-1551.

88 Humbert M, Trembath RC. Genetics of pulmonary hypertension: from bench to bedside. Eur Respir J 2002; 20: 741-749.

89 Mellies U, Lofaso F. Pompe disease: a neuromuscular disease with respiratory muscle involvement. Respir Med 2009; 103: 477-484.

90 Bembi B, Cerini E, Danesino C, et al. Diagnosis of glycogenosis type II. Neurology 2008; 71: 4-11.

Kishnani PS, Howell RR. Pompe disease in infants and children. I Pediatr 2004; 144: 35-43.

Bembi B, Cerini E, Danesino C, et al. Management and treatment of glycogenosis type II. Neurology 2008; 71 : $12-36$.

93 van der Beek NA, van Capelle CI, van der Velden-van Etten KI, et al. Rate of progression and predictive factors for pulmonary outcome in children and adults with Pompe disease. Mol Genet Metab 2011; 104: 129-136. 
94 Pellegrini N, Laforet $\mathrm{P}$, Orlikowski D, et al. Respiratory insufficiency and limb muscle weakness in adults with Pompe's disease. Eur Respir J 2005; 26: 1024-1031.

95 Neufeld EF, Muenzer J. The mucopolysaccharidoses. In: Scriver CR, Beaudet AL, Sly WS et al., eds. The Metabolic and Molecular Bases of Inherited Disease. 8th Edn. New York, McGraw-Hill, 2001; pp. 3421-3452.

96 Orliaguet O, Pepin JL, Veale D, et al. Hunter's syndrome and associated sleep apnoea cured by CPAP and surgery. Eur Respir J 1999; 13: 1195-1197.

97 Semenza GL, Pyeritz RE. Respiratory complications of mucopolysaccharide storage disorders. Medicine 1988; 67: 209-219.

98 Lin HY, Chen MR, Lin CC, et al. Polysomnographic characteristics in patients with mucopolysaccharidoses. Pediatr Pulmonol 2010; 45: 1205-1212.

99 Papsin BC, Vellodi A, Bailey CM, et al. Otologic and laryngologic manifestations of mucopolysaccharidoses after bone marrow transplantation. Otolaryngol Head Neck Surg 1998; 118: 30-36.

100 Pritzker MR, King RA, Kronenberg RS. Upper airway obstruction during head flexion in Morquio's disease. Am J Med 1980; 69: 467-470.

101 Shinhar SY, Zablocki H, Madgy DN. Airway management in mucopolysaccharide storage disorders. Arch Otolaryngol Head Neck Surg 2004; 130: 233-237.

102 Walker PP, Rose E, Williams JG. Upper airways abnormalities and tracheal problems in Morquio's disease. Thorax 2003; 58: 458-459.

103 Nashed A, Al-Saleh S, Gibbons J, et al. Sleep-related breathing in children with mucopolysaccharidosis. J Inherit Metab Dis 2009; 32: 544-550.

104 Muhlebach MS, Wooten W, Muenzer J. Respiratory manifestations in mucopolysaccharidoses. Paediatr Respir Rev 2011; 12: 133-138.

105 Leighton SE, Papsin B, Vellodi A, et al. Disordered breathing during sleep in patients with mucopolysaccharidoses. Int J Pediatr Otorhinolaryngol 2001; 58: 127-138.

106 Pelley CJ, Kwo J, Hess DR. Tracheomalacia in an adult with respiratory failure and Morquio syndrome. Respir Care 2007; 52: 278-282.

107 Simmons MA, Bruce IA, Penney S, et al. Otorhinolaryngological manifestations of the mucopolysaccharidoses. Int J Pediatr Otorhinolaryngol 2005; 69: 589-595.

108 Bredenkamp JK, Smith ME, Dudley JP, et al. Otolaryngologic manifestations of mucopolysaccharidoses. Ann Otol Rhinol Laryngol 1992; 101: 472-478.

109 Arn P, Whitley C, Wraith JE, et al. High rate of postoperative mortality in patients with mucopolysaccharidosis I: findings from the MPS I Registry. J Pediatr Surg 2012; 47: 477-484.

110 Muhlebach MS, Shaffer CB, Georges L, et al. Bronchoscopy and airway management in patients with mucopolysaccharidoses (MPS). Pediatr Pulmonol 2013; 48: 601-607.

111 Wold SM, Derkay CS, Darrow DH, et al. Role of the pediatric otolaryngologist in diagnosis and management of children with mucopolysaccharidoses. Int J Pediatr Otorhinolaryngol 2010; 74: 27-31.

112 Frawley G, Fuenzalida D, Donath S, et al. A retrospective audit of anesthetic techniques and complications in children with mucopolysaccharidoses. Paediatr Anaesth 2012; 22: 737-744.

113 Santamaria F, Andreucci MV, Parenti G, et al. Upper airway obstructive disease in mucopolysaccharidoses: polysomnography, computed tomography and nasal endoscopy findings. J Inherit Metab Dis 2007; 30: 743-749.

114 Chung MJ, Lee KS, Franquet T, et al. Metabolic lung disease: imaging and histopathologic findings. Eur J Radiol 2005; 54: 233-245.

115 Tabak L, Yilmazbayhan D, Kiliçaslan Z, et al. Value of bronchoalveolar lavage in lipidoses with pulmonary involvement. Eur Respir J 1994; 7: 409-411.

116 Wells AU. The clinical utility of bronchoalveolar lavage in diffuse parenchymal lung disease. Eur Respir Rev 2010; 19: 237-241.

117 Gülhan B, Ozçelik U, Gürakan F, et al. Different features of lung involvement in Niemann-Pick disease and Gaucher disease. Respir Med 2012; 106: 1278-1285.

118 Fecarotta S, Amitrano M, Romano A, et al. The videofluoroscopic swallowing study shows a sustained improvement of dysphagia in children with Niemann-Pick disease type C after therapy with miglustat. Am J Med Genet A 2011; 155: 540-547.

119 van der Ploeg AT. Monitoring of pulmonary function in Pompe disease: a muscle disease with new therapeutic perspectives. Eur Respir J 2005; 26: 984-985.

120 Prigent H, Orlikowski D, Laforêt P, et al. Supine volume drop and diaphragmatic function in adults with Pompe disease. Eur Respir J 2012; 39: 1545-1546.

121 Mundy HR, Georgiadou P, Davies LC, et al. Exercise capacity and biochemical profile during exercise in patients with glycogen storage disease type I. J Clin Endocrinol Metab 2005; 90: 2675-2680.

122 Taivassalo T, Jensen TD, Kennaway N, et al. The spectrum of exercise tolerance in mitochondrial myopathies: a study of 40 patients. Brain 2003; 126: 413-423.

123 Lévy P, Tamisier R, Minville C, et al. Sleep apnoea syndrome in 2011: current concepts and future directions. Eur Respir Rev 2011; 20: 134-146.

124 Bersanini C, Khirani S, Ramirez A, et al. Nocturnal hypoxaemia and hypercapnia in children with neuromuscular disorders. Eur Respir J 2012; 39: 1206-1212.

125 Ramadan HK, Mackinlay CI, Nicholson AG. A woman in her mid 30s with a dry cough and breathlessness. Thorax 2009; 64: 644.

126 Kishnani PS, Hwu WL, Mandel H, et al. A retrospective, multinational, multicenter study on the natural history of infantile-onset Pompe disease. J Pediatr 2006; 148: 671-676.

127 van den Hout HM, Hop W, van Diggelen OP, et al. The natural course of infantile Pompe's disease: 20 original cases compared with 133 cases from the literature. Pediatrics 2003; 112: 332-340.

128 Mellies U, Stehling F, Dohna-Schwake C, et al. Respiratory failure in Pompe disease: treatment with noninvasive ventilation. Neurology 2005; 64: 1465-1467.

129 Ginzburg AS, Onal E, Aronson RM, et al. Successful use of nasal-CPAP for obstructive sleep apnoea in Hunter syndrome with diffuse airway involvement. Chest 1990; 97: 1496-1498. 
130 Douda DN, Farmakovski N, Dell S, et al. SP-D counteracts GM-CSF-mediated increase of granuloma formation by alveolar macrophages in lysinuric protein intolerance. Orphanet J Rare Dis 2009; 4: 29.

131 Ceruti M, Rodi G, Stella GM, et al. Successful whole lung lavage in pulmonary alveolar proteinosis secondary to lysinuric intolerance: a case report. Orphanet J Rare Dis 2007; 2: 14.

132 O'Brien K, Troendle J, Gochuico BR, et al. Pirfenidone for the treatment of Hermansky-Pudlak syndrome pulmonary fibrosis. Mol Genet Metab 2011; 103: 128-134.

133 Rouhani FN, Brantly ML, Markello TC, et al. Alveolar macrophage dysregulation in Hermansky-Pudlak syndrome type 1. Am J Respir Crit Care Med 2009; 180: 1114-1121.

134 Schaefer CJ, Ruhrmund DW, Pan L, et al. Antifibrotic activities of pirfenidone in animal models. Eur Respir Rev 2011; 20: 85-97.

135 Parenti G. Treating lysosomal storage diseases with pharmacological chaperones: from concept to clinics. EMBO Mol Med 2009; 1: 268-279.

136 Trapero A, González-Bulnes P, Butters TD, et al. Potent aminocyclitol glucocerebrosidase inhibitors are subnanomolar pharmacological chaperones for treating gaucher disease. J Med Chem 2012; 55: 4479-4488.

137 Porto C, Pisani A, Rosa M, et al. Synergy between the pharmacological chaperone 1-deoxygalactonojirimycin and the human recombinant alpha-galactosidase A in cultured fibroblasts from patients with Fabry disease. J Inherit Metab Dis 2012; 35: 513-520.

138 Victor S, Coulter JB, Besley GT, et al. Niemann-Pick disease: sixteen-year follow-up of allogeneic bone marrow transplantation in a type B variant. J Inherit Metab Dis 2003; 26: 775-785.

139 Pineda M, Wraith JE, Mengel E, et al. Miglustat in patients with Niemann-Pick disease Type C (NP-C): a multicenter observational retrospective cohort study. Mol Genet Metab 2009; 98: 243-249.

140 Goitein O, Elstein D, Abrahamov A, et al. Lung involvement and enzyme replacement therapy in Gaucher's disease. OJM 2001; 94: 407-415.

141 Altarescu G, Hill S, Wiggs E, et al. The efficacy of enzyme replacement therapy in patients with chronic neuronopathic Gaucher's disease. J Pediatr 2001; 138: 539-547.

142 Zimran A, Elstein D. Gaucher disease and the clinical experience with substrate reduction therapy. Philos Trans $R$ Soc Lond B Biol Sci 2003; 358: 961-966.

143 Marshall J, McEachern KA, Chuang WL, et al. Improved management of lysosomal glucosylceramide levels in a mouse model of type 1 Gaucher disease using enzyme and substrate reduction therapy. J Inherit Metab Dis 2010; 33: 281-289.

144 Schiffmann R, Fitzgibbon EJ, Harris C, et al. Randomized, controlled trial of miglustat in Gaucher's disease type 3. Ann Neurol 2008; 64: 514-522.

145 Wang RY, Abe JT, Cohen AH, et al. Enzyme replacement therapy stabilizes obstructive pulmonary Fabry disease associated with respiratory globotriaosylceramide storage. J Inherit Metab Dis 2008; 31: 369-374.

146 Kishnani PS, Corzo D, Leslie ND, et al. Early treatment with alglucosidase alpha prolongs longterm survival of infants with Pompe disease. Pediatr Res 2009; 66: 329-335.

147 Nicolino M, Byrne B, Wraith JE, et al. Clinical outcomes after long-term treatment with alglucosidase alfa in infants and children with advanced Pompe disease. Genet Med 2009; 11: 210-219.

148 Chien YH, Lee NC, Thurberg BL, et al. Pompe disease in infants: improving the prognosis by newborn screening and early treatment. Pediatrics 2009; 124: 1116-1125.

149 van der Ploeg AT, Clemens PR, Corzo D, et al. A randomized study of alglucosidase alfa in late-onset Pompe's disease. N Engl J Med 2010; 362: 1396-1406.

150 Regnery C, Kornblum C, Hanisch F, et al. 36 months observational clinical study of 38 adult Pompe disease patients under alglucosidase alfa enzyme replacement therapy. J Inherit Metab Dis 2012; 35: 837-845.

151 Orlikowski D, Pellegrini N, Prigent H, et al. Recombinant human acid alpha-glucosidase (rhGAA) in adult patients with severe respiratory failure due to Pompe disease. Neuromuscul Disord 2011; 21: 477-482.

152 Porto C, Cardone M, Fontana F, et al. The pharmacological chaperone N-butyldeoxynojirimycin enhances enzyme replacement therapy in Pompe disease fibroblasts. Mol Ther 2009; 17: 964-971.

153 Parenti G, Andria G. Pompe disease: from new views on pathophysiology to innovative therapeutic strategies. Curr Pharm Biotechnol 2011; 12: 902-915.

154 Harmatz P, Giugliani R, Schwartz I, et al. Enzyme replacement therapy for mucopolysaccharidosis VI: a phase 3, randomized, double-blind, placebo-controlled, multinational study of recombinant human $\mathrm{N}$-acetylgalactosamine 4-sulfatase (recombinant human arylsulfatase B or rhASB) and follow-on, open-label extension study. J Pediatr 2006; 148: 533-539.

155 Kakkis ED, Muenzer J, Tiller GE, et al. Enzyme replacement therapy in mucopolysaccharidosis I. N Engl J Med 2001; 344: 182-188.

156 Wraith JE. The first 5 years of clinical experience with laronidase enzyme replacement therapy for mucopolysaccharidosis I. Expert Opin Pharmacother 2005; 6: 489-506.

157 Muenzer J, Wraith JE, Beck M, et al. A phase II/III clinical study of enzyme replacement therapy with idursulfase in mucopolysaccharidosis II (Hunter syndrome). Genet Med 2006; 8: 465-473.

158 Valayannopoulos V, de Blic J, Mahlaoui N, et al. Laronidase for cardiopulmonary disease in Hurler syndrome 12 years after bone marrow transplantation. Pediatrics 2010; 126: 1242-1247.

159 Harmatz P, Yu ZF, Giugliani R, et al. Enzyme replacement therapy for mucopolysaccharidosis VI: evaluation of long-term pulmonary function in patients treated with recombinant human $\mathrm{N}$-acetylgalactosamine 4 sulfatase. J Inherit Metab Dis 2010; 33: 51-60.

160 Lin HY, Chen MR, Chuang CK, et al. Enzyme replacement therapy for mucopolysaccharidosis VI-experience in Taiwan. J Inherit Metab Dis 2010 [In press DOI: 10.1007/s10545-010-9212-5]

161 Wraith JE, Clarke LA, Beck M, et al. Enzyme replacement therapy for mucopolysaccharidosis I: a randomized, double-blinded, placebo-controlled, multinational study of recombinant human $\alpha$-L-iduronidase (laronidase). J Pediatr 2004; 144: 581-588.

162 Allen JL. Treatment of respiratory system (not just lung!) abnormalities in mucopolysaccharidosis I. J Pediatr 2004; 144: $561-562$. 
163 Kirkpatrick K, Ellwood J, Walker RW. Mucopolysaccharidosis type I (Hurler syndrome) and anesthesia: the impact of bone marrow transplantation, enzyme replacement therapy, and fiberoptic intubation on airway management. Paediatr Anaesth 2012; 22: 745-751.

164 Peters C, Steward CG. Hematopoietic cell transplantation for inherited metabolic diseases: an overview of outcomes and practice guidelines. Bone Marrow Transplant 2003; 31: 229-239.

165 Beck M. Therapy for lysosomal storage disorders. IUBMB Life 2010; 62: 33-40.

166 Valayannopoulos V, Wijburg FA. Therapy for the mucopolysaccharidoses. Rheumatology 2011; 50: 49-59.

167 Yeung AH, Cowan MJ, Horn B, et al. Airway management in children with mucopolysaccharidoses. Arch Otolaryngol Head Neck Surg 2009; 135: 73-79.

168 Belani KG, Krivit W, Carpenter BL, et al. Children with mucopolysaccharidosis: perioperative care, morbidity, mortality, and new findings. J Pediatr Surg 1993; 28: 403-408. 